\title{
ARTÍCULOS
}

\section{Parmotrema species in a cloud forest region turned into an urban zone in Xalapa, Veracruz, Mexico}

\author{
Especies de Parmotrema en un bosque mesófilo de montaña convertido en \\ zona urbana en Xalapa, Veracruz, México
}

\author{
Rosa Emilia Pérez-Pérez ${ }^{a *}$, Gastón Guzmán ${ }^{\text {b }}$ \\ *Corresponding author: ${ }^{a}$ Benemérita Universidad Autónoma de Puebla, Escuela de Biología, Laboratorio de Biología Vegetal y \\ Micología, Blv. Valsequillo y Av. San Claudio, Edif. 112 A, Ciudad Universitaria, Col. Jardines de San Manuel, CP 72570, \\ Puebla, México, emilia.perez@correo.buap.mx

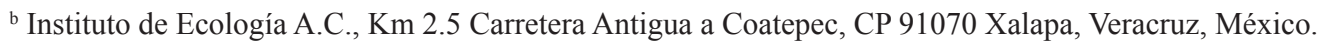

\begin{abstract}
SUMMARY
The cloud forest of Mexico has the highest biodiversity among the country's diverse forest types; however, $90 \%$ of the cloud forest ecosystem in the region of Xalapa has been destroyed and what remains is at risk. This region is home to an enormous diversity of lichen species. In a lichen survey carried out in this remnant of cloud forest in Xalapa, which has been turned into an urban area, we identified only eight species of Parmotrema, all of which showed vegetative propagules. Regardless of the role of the genus in the ecosystems, these lichens may be disappearing as a result of the transformation and destruction of the cloud forest ecosystem in Mexico.
\end{abstract}

Key words: Parmotrema, cloud forest, Xalapa Region, Mexico.

\section{RESUMEN}

El bosque mesófilo de montaña es de los ecosistemas más diversos que hay en el México; sin embargo, en la región de Xalapa el 90 \% ha sido destruido y el resto está en riesgo. La región alberga gran diversidad de líquenes. En este sitio de estudio, que fue un remanente de bosque mesófilo de montaña transformado a zona urbana, se identificaron solo ocho especies pertenecientes al género Parmotrema, todas ellas presentaron propágulos vegetativos. No obstante la importancia del género en los ecosistemas, estos líquenes están en riesgo de desaparecer como resultado de la transformación y destrucción del ecosistema en México.

Palabras clave: Parmotrema, bosque mesófilo, región de Xalapa, México.

\section{INTRODUCTION}

Corticolous lichens such as the genus Parmotrema A. Massal face extinction due to their inability to disperse, settle and colonize in declining forests. Corticolous lichens depend directly on the quality of bark substratum and high microhabitat heterogeneity of tree trunks for their settlement and survival (Hauck et al. 2001). Seaward (2008) suggests that a potential factor influencing epiphytic lichen individuals and populations may be the quality and longevity of the substratum trees. Tree mortality is a common cause of local extinctions of epiphyte meta-populations (Snäll et al. 2003). A survival strategy for some foliose lichens is to produce asexual propagules to disperse the fungal and photobiont cells together. The most common categories of these asexual propagules are soredia, isidia and thallus fragments (Armstrong 1991), which are scattered by wind, water and animals. The- se vegetative strategies provide a superior survival rate for propagules, since lichens can more rapidly invade new habitats, and, under favorable conditions, grow into new thalli (Bowler and Rundel 1975). Veracruz is one of the Mexican states with the highest richness of known lichens (700), and cloud forests shelter ca. 250 species (Herrera-Campos et al. 2014). The main focus of this study is to find out how many species of Parmotrema have been able to survive, since most of the cloud forest ecosystem was first turned into coffee plantations and then eventually into urban areas.

\section{METHODS}

Study site. The study was carried out in an urban area of the Zoncuantla region, along Camino Antiguo (old road) Xalapa-Coatepec, about $6 \mathrm{~km}$ south of Xalapa in the State of Veracruz. The area is approximately $1,000 \mathrm{~m}^{2}$. The site 
is located at $19^{\circ} 29^{\prime} 56^{\prime \prime} \mathrm{N}$ and $96^{\circ} 56^{\prime} 40^{\prime \prime} \mathrm{W}$, at an altitude of $1,300 \mathrm{~m}$ (figure 1). The climate is temperate with a mean annual temperature of $19.2^{\circ} \mathrm{C}$. The mean annual precipitation is $1,926 \mathrm{~mm}$, with rains in summer and autumn. The original vegetation in the study geographical area was that of cloud forests (figure 2A), which gradually decreased during last century until 1960, due to the expansion of coffee plantations; later on, the transformation of the ecosystem was caused by demographic fast-growth. Currently, $90 \%$ of this forest has been destroyed and what remains is at risk of disappearing (Williams-Linera et al. 2002).

Lichen sampling and taxonomic identification. Lichens were surveyed by the second author of this article over a 14 year period in an urban area, taken primarily from fallen trees and branches (figure $3 \mathrm{~A}$ ) of remaining trees of Platanus mexicana Moric, Quercus xalapensis Bonpl., $Q$. laurina Bonpl., Inga jinicuil Schltdl. and Ulmus mexicana Planch. Collected specimens were identified by the first author reviewing the macroscopic and microscopic characters with a compound microscope Axiostar Plus Zeiss and a stereoscopic microscope Zeiss Stemi model DV4, making the color test and following the corresponding key. Finally, Dr. Robert Egan (Omaha, Nebraska) confirmed the identifications. Voucher specimens are deposited at the Colección de Hongos (XAL) of Instituto de Ecología A.C.

\section{RESULTS}

We found thirteen genera belonging to three families: Candelariaceae, Physciaceae and Parmeliaceae. In this stu- dy, we only focused on Parmotrema lichens. One hundred and twenty specimens were collected, 34 of them were too small or lacked reproductive structures to allow identification to species level. Lichen richness and coverage decline as urbanization increases. Evidence of it is that, at this particular site, we only identified eight species of Parmotre$m a$; and all of them showed vegetative propagules (table 1 , figures 1,2).

Table 1. Species identified in a remnant of cloud forest in Zoncuantla, Xalapa, Veracruz.

Especies identificadas en un remanente de bosque mesófilo de montaña en Zoncuantla, Xalapa, Veracruz.

\begin{tabular}{ll}
\hline \multicolumn{1}{c}{ Species } & $\begin{array}{c}\text { Reproductive } \\
\text { structures }\end{array}$ \\
\hline Parmotrema austrosinense (Zahlbr.) Hale & Soredia \\
Parmotrema hababianum (Gyelnik) Hale & Soredia \\
Parmotrema praesorediosum (Nyl.) Hale & Soredia \\
Parmotrema reticulatum (Taylor) M. Choisy & Soredia \\
Parmotrema sancti-angelii (Lynge) Hale & Soredia \\
Parmotrema subisidiosum (Müll. Arg.) Hale & Isidia \\
Parmotrema subtinctorium (Zahlbr.) Hale & Isidia \\
Parmotrema tinctorum (Delise ex Nyl.) Hale & Isidia \\
\hline
\end{tabular}

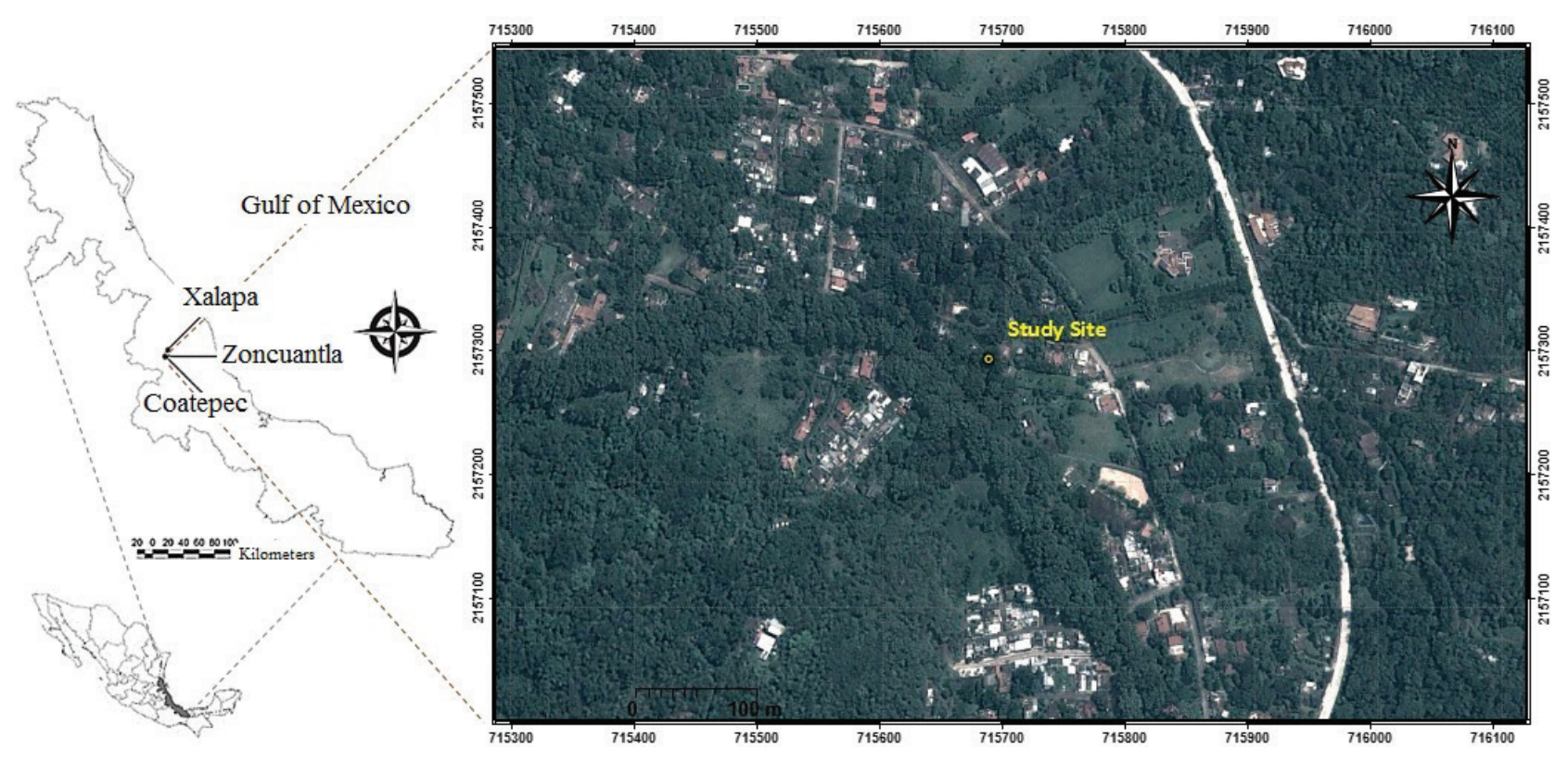

Figure 1. Geographic situation of the Zoncuantla region, located between Xalapa and Coatepec, State of Veracruz, Mexico (developed by C Sandoval and J Ramírez).

Ubicación geográfica de la región de Zoncuantla, entre Xalapa y Coatepec, en el estado de Veracruz, México (elaborada por C Sandoval y J Ramírez). 



Figure 2. A) Remnant of a Cloud forest in La Cortadura, Coatepec, Veracruz, Mexico. B) Parmotrema austrosinense. C) Parmotrema hababianum. D) Parmotrema praesorediosum. E) Parmotrema reticulatum. (Herbarium specimens) Photos by RE Pérez-Pérez.

A) Remanente de un bosque mesófilo de montaña en La Cortadura, Coatepec, Veracruz, México. B) Parmotrema austrosinense, C) Parmotrema hababianum, D) Parmotrema praesorediosum, E) Parmotrema reticulatum. (Material de herbario). Fotografías de RE Pérez-Pérez. 

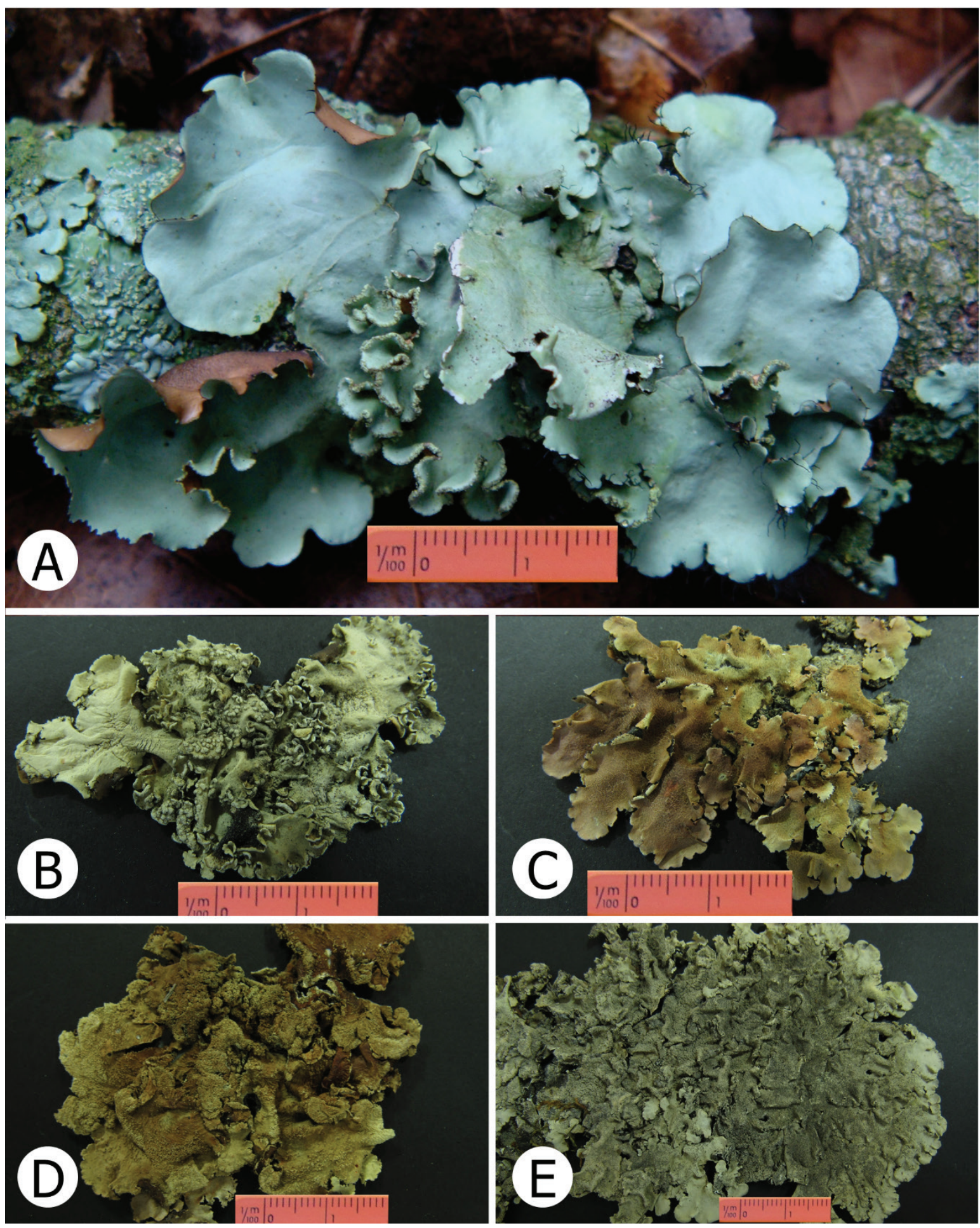

Figure 3. A) Fallen branch with species of Parmotrema. B) Parmotrema sancti-angelii. C) Parmotrema subisidiosum. D) Parmotrema subtinctorium. E) Parmotrema tinctorum. (Herbarium specimens) Photo A by F Ramírez Guillen, photos B-E by RE Pérez-Pérez.

A) Rama caída con especies de Parmotrema. B) Parmotrema sancti-angelii. C) Parmotrema subisidiosum. D) Parmotrema subtinctorium. E) Parmotrema tinctorum. (Material de herbario). Fotografías: F. Ramírez Guillen (A), RE Pérez-Pérez (B-E). 


\section{DISCUSSION}

There are more than 300 species of Parmotrema worldwide (Hinds and Hinds 2007), with 224 species widely distributed in tropical regions around the world (Hale and DePriest 1999) and nearly 100 are from Mexico (Nash III and Elix 2002); some of them were considered endemic to Mexico by Hale (1965). One of these, Parmotrema mirandum (Hale) was reported for the first time in the Mexican states of Guerrero and Morelos. It is one of the few records including Hypoconstictic acid as a major secondary metabolite and points out this substance as a major diagnostic secondary metabolite for Parmotrema spp. (Pérez-Pérez et al. 2011a).

Regarding the propagules, Bowler and Rundel (1975) suggest that propagation through vegetative diaspores appears to allow higher survival rates. However, Johansson (2008) showed that lichen populations might need a long time to recover, though that species richness does not necessarily increase over time. In fact, corticolous lichens are slow-growing and slow to colonize new ecosystems due to their sensitivity to environmental changes (Wolseley and Aguirre-Hudson 1997). Lichen populations are likely to become extinct when their phorophyte substrates are limited to a very low diversity (Sheidegger et al. 1995).

Tropical montane cloud forests support the most diverse fauna and flora per square meter in Mexico in spite of the creation of coffee plantations, land pasture areas and urbanization sites (Williams-Linera 1993). Being epiphytes the most diverse biological group in the ecosystem (Williams-Linera 2012), just like the lichens. Lichens play a very important role in the nutrients cycle (Nash 2008). For instance, among animals including mice and bats, lichens are used as food (Kumor et al. 2009), and some birds use Parmotrema spp. lichens as nesting material (Maurício et al. 2013, Mercado-Díaz et al. 2015).

In studies conducted in the coniferous forests of Mexi$\mathrm{co}$, the Parmeliaceae family is the most representative, and the genus Parmotrema is one of the most diverse and conspicuous (Pérez-Pérez et al. 2008, 2011b, Herrera-Campos et al. 2014), probably due to its long distance dispersal capability by means of wind and/or birds (Elix and Gremmen 2002). Unfortunately, lichen diversity has declined along with the transformation of ecosystems. Even if some valuable trees survive over the course of these developments, their lichen biota is likely to become depleted over time (Lättman et al. 2014) which will decrease lichen populations, size and diversity (Öckinger and Nilsson 2010).

In the state of Veracruz studies have focused on foliicolous lichens and some macrolichens (Brizuela and Guzmán 1971, Herrera-Campos and Lücking 2002, HerreraCampos et al. 2004). Though in the Xalapa region lichen studies are scarce (Palacios et al. 1999). There are two studies in a remnant of cloud forest at La Cortadura, Coatepec, Veracruz; one of them describes three new corticolous lichen species (Córdova-Chávez et al. 2014). On the other hand, Pérez-Pérez et al. (2015) reported 108 lichens species, 36 belonging to the Parmeliaceae family and 14 to the genus Parmotrema. Using Parmotrema spp. here as a model group, we suggest that these foliose lichens in the Xalapa region are declining due to environmental changes in the cloud forest ecosystem caused by the loss of suitable corticolous substrates; therefore, it is necessary to immediately implement conservation programs to try and preserve what remains of this ecosystem, if possible (Guzmán 2013).

\section{CONCLUSIONS}

The lichen flora of the cloud forest regions of Mexico has extremely high lichen species richness; nevertheless, it is endangered due to human activities, such as the creation of coffee plantations, land pasture areas and urbanization sites. Despite the ability of some lichen taxa to disperse and survive in cloud forest remnants using asexual vegetative propagules, we need to complete a detailed inventory of the lichen biodiversity of Mexican could forests before these forests are lost forever; especially if we take into account the importance of the Parmotrema genus for the ecosystem.

\section{ACKNOWLEDGEMENTS}

The authors would like to thank Dr. Robert Egan for the confirmation of specimens, Florencia Ramírez Guillén and Juan Carmona for their support in the Laboratory, Herbarium and on field work. Anonymous referees and Salvador Guerra for improving the manuscript.

\section{REFERENCES}

Armstrong RA. 1991. The influence of climate on the dispersal of lichen soredia. Environmental and Experimental Botany 31: 239-245.

Bowler PA, PW Rundel. 1975. Reproductive strategies in lichens. Botanical Journal of the Linnean Society 70: 325-340.

Brizuela F, G Guzmán. 1971. Estudios sobre los líquenes de México, II. Boletín de la Sociedad Mexicana de Micología 5: 79-103.

Córdova-Chávez O, A Aptroot, G Castillo-Campos, ME Cáceres, RE Pérez-Pérez. 2014. Three new lichen species from cloud forest in Veracruz, México. Cryptogamie, Mycologie 35(2): 157-162.

Elix JA, NJM Gremmen. 2002. The Lichen family Parmeliaceae (Ascomycotina) on Gough Island, South Atlantic Ocean. Mycotaxon LXXXI: 257-264.

Hale ME Jr. 1965. A monograph of Parmelia subgenus Amphigymnia. Contribution from the United States National Herbarium 36(5): 193-358.

Hale BM, P Depriest. 1999. Mason E. Hale's list of epithets in the parmelioid genera. The Bryologist 102: 462-544.

Hauck M, R Jung, M Runge. 2001. Relevance of element content of bark for the distribution of epiphytic lichens in a Montane spruce forest affected by forest dieback. Environmental 
Pollution 112: 221-227.

Herrera-Campos MA, R Lücking. 2002. The foliicolous lichen flora of Mexico. I. New species from Los Tuxtlas Tropical Biology Station, Veracruz. Lichenologist 34: 211-222.

Herrera-Campos MA, R Lücking, RE Pérez, A Campos, PM Colin, AB Peña. 2004. The foliicolous lichen flora of Mexico. V. Biogeographical affinities, altitudinal preferences and an updated checklist of 293 species. Lichenologist 36 (5): 309-327.

Herrera-Campos MA, R Lücking, RE Pérez-Pérez, R MirandaGonzález, N Sánchez, A Barcenas-Peña, A Carrizosa, A Zambrano, BD Ryan, TH Nash III. 2014. Biodiversidad de Líquenes. Revista Mexicana de Biodiversidad, Supl 85: 82-99.

Hinds JM, PL Hinds. 2007. The macrolichens of New England. New Yory, USA. The New York Botanical Garden Press. $544 \mathrm{p}$.

Guzmán G. 2013. Devastación de los bosques y selvas en México, la urgencia de su conservación. Xalapa, México. Instituto de Ecología. 68 p.

Johansson P. 2008. Consequences of disturbance on epiphytic lichens in boreal and near boreal forests. Biological Conservation 141: 1933-1944.

Kumar B, DK Upreti, SP Singh, A Tiwari. 2009. Seasonal pattern of lichen fall from trees in an evergreen Quercus semecarpifolia forest of Garhwal Himalaya, India. Nature and Science 7(3): 8-12.

Lättman H, KO Bergman, M Rapp, M Tälle, L Westerberg, P Milberg. 2014. Decline in lichen biodiversity on oak trunks due to urbanization. Nordic Journal of Botany 32(4): 518-528.

Maurício GN, GA Bencke, M Repenning, DB Machado, RA Dias, L Bugoni. 2013. Review of the breeding status of birds in Rio Grande do Sul, Brazil. Iheringia, Série Zoologia (Porto Alegre) 103(2): 163-184.

Mercado-Díaz JA, WA Gould, G González, R Lücking, 2015. Lichens in Puerto Rico: an ecosystem approach. San Juan, Puerto Rico. US Department of Agriculture, Forest Service, International Institute of Tropical Forestry. 76 p. (Gen. Tech. Rep. IITF-GTR-46).

Nash III TH. 2008. Lichen Biology. Cambridge, UK. Cambridge University Press. 486 p.

Nash III TH, JA Elix. 2002. Parmotrema. In Nash III TH, BD Ryan, C Gries, F Bungartz eds. Lichen Flora of Greater Sonoran Desert Region. Volume 1. Tempe, Arizona. Arizona State University. p. 318-329.

Öckinger E, SV Nilsson. 2010. Local population extinction and vitality of an epiphytic lichen in fragmented old-growth forest. Ecology 91: 2100-2109.
Palacios D, G Parrilla, JJ Zamorano. 1999. Paraglacial and postglacial debris flows on a Little Ice Age terminal moraine: Jamapa Glacier, Pico de Orizaba (Mexico). Geomorphology 28: 95-118

Pérez-Pérez RE, G Castillo-Campos, MES Cáceres. 2015. Diversity of corticolous lichens in Cloud Forest remnants in La Cortadura, Coatepec, Veracruz, México in relation to phorophytes and habitat fragmentation. Cryptogamie, Mycologie 36(1): 79-92.

Pérez-Pérez RE, RS Egan, TH Nash III, JA Elix. 2011a. Parmotrema mirandum (Hale) Hale: revised chemistry and new records from Guerrero and Morelos, Mexico. The Bryologist 114(3): 474-476.

Pérez-Pérez RE, N Miramontes Rojas, J Aguilar Rosales, H Quiroz Castelán. 2008. Macrolíquenes cortícolas en coníferas del Parque Nacional Lagunas de Zempoala. Universidad de Guanajuato. Revista Acta Universitaria 18: 33-39.

Pérez-Pérez RE, H Quiroz, MA Herrera-Campos, R García Barrios. 2011b. Scale-dependent effects of management on the richness and composition of corticolous macrolichens in pine-oak forests of Sierra de Juárez, Oaxaca, Mexico. Bibliotheca Lichenologica 106: 243-258.

Seaward MRD. 2008. Environmental role of lichens. In Nash III T ed. Lichen Biology. Cambridge, UK. Cambridge University Press. p. 274-298.

Sheidegger C, B Frey, S Zoller. 1995. Transplantation of symbiotic propagules and thallus fragments: methods for the conservation of threatened epiphytic lichen populations. Mitteilungen der Eidgenössischen Forschungsanstalt für Wald, Schnee und Landschaft 70 (1): 41-62.

Snäll T, PPJJR Ribeiro, H Rydin. 2003. Spatial occurrence and colonisations in patch-tracking metapopulations: local conditions versus dispersal. Oikos 103: 566-578.

Williams-Linera G. 1993. Bordes de bosque nublado en el Parque Ecológico Clavijero, Xalapa, Veracruz, México. Revista de Biología Tropical 41: 107-117.

Williams-Linera G. 2012. El bosque de niebla del centro de Veracruz: ecología, historia y destino en tiempos de fragmentación y cambio climático. Xalapa, México. CONABIOInstituto de Ecología. 204 p.

Williams-Linera G, RH Manson, E Isunza Vera. 2002. La fragmentación del bosque mesófilo de montaña y patrones de uso del suelo en la región oeste de Xalapa, Veracruz, México. Madera y Bosques 8: 73-89.

Wolseley PA, B Aguirre-Hudson. 1997. Fire in tropical dry forests: corticolous lichens as indicators of recent ecological changes in Thailand. Journal of Biogeography 24: 345-362. 